\title{
Influence of Zirconium Content on Corrosion Resistance of Micro-Alloyed Steel Reinforced Concrete in Chloride Solutions
}

\author{
Shi Shao Hua \\ School of Architectural Engineering Sichuan University of Arts and Science, Dazhou, \\ Sichuan Province, 635000, China \\ E-mail: $\underline{\text { sshssh080612@ @ina.com }}$ \\ doi: $10.20964 / 2020.05 .84$
}

Received: 13 January 2020/ Accepted: 6 March 2020 / Published: 10 April 2020

\begin{abstract}
Corrosion resistance of zirconium( $\mathrm{Zr})$ micro-alloyed steel rebar in the artificial seawater environment were investigated by electrochemical technique. Electrochemical impedance spectroscopy (EIS) and potentiodynamic polarization techniques were used to study the effect of $\mathrm{Zr}$ content on corrosion behavior of carbon steel rebars. The polarization plots show that the steel rebar with $0.15 \mathrm{wt} \% \mathrm{Zr}$ content had a smaller corrosion current-density than the other samples which was in the passive state during the test.The EIS results indicate that double-layer capacitance value is reduced with the increase of $Z r$ content which reveals that the passive film thickness increased resulting in an enhanced protective capacity when the $\mathrm{Zr}$ content of steel rebar gradually increased. The EIS results are in accordance with the best-fit findings for double-layer capacitance at the steel-concrete interface which were gradually increased over $4.5 \mu \mathrm{Fcm}^{-2}$ with $3 \mathrm{wt} \% \mathrm{NaCl}$ in the artificial seawater, demonstrating that produced corrosion may occur on the surface of steel rebar.
\end{abstract}

Keywords:Zirconium micro-alloyed steel reinforced concrete; Corrosion resistance; Chloride concentration; Electrochemical technique

\section{$\underline{\text { FULL TEXT }}$}

(C) 2020 The Authors. Published by ESG (www.electrochemsci.org). This article is an open access article distributed under the terms and conditions of the Creative Commons Attribution license (http://creativecommons.org/licenses/by/4.0/). 